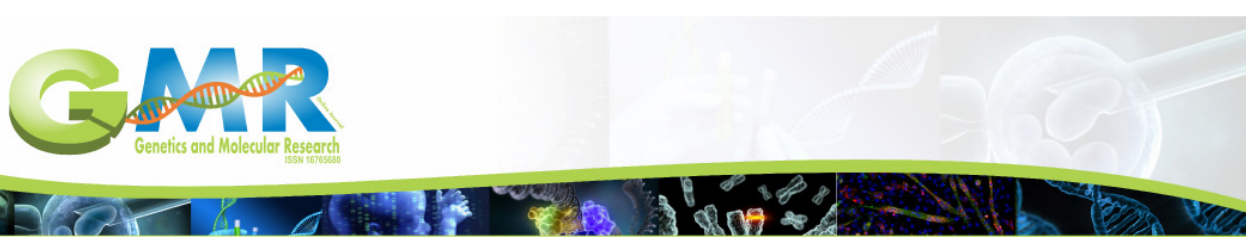

\title{
Microsatellite loci and genetic structure of artificial populations of Cotesia flavipes (Hymenoptera, Braconidae)
}

L.O.S. Anjos ${ }^{1}$, R.F. Peixoto Jr' ${ }^{1}$, D.M.S. Chanquinie ${ }^{1}$, L.R. Pinto ${ }^{1}$, S.A. Creste ${ }^{1}$, L.L. Dinardo-Miranda ${ }^{1}$, M.G.A. Landell ${ }^{1}$, E.V. Tambarussi ${ }^{2,3}$ and R. Vencovsky ${ }^{2 \dagger}$

Instituto Agronômico, Centro de Cana, Ribeirão Preto, SP, Brasil

${ }^{2}$ Departamento de Genética, Escola Superior de Agricultura Luiz de Queiroz, Universidade de São Paulo, Piracicaba, SP, Brasil

${ }^{3}$ Departamento de Engenharia Florestal, Universidade Estadual do Centro-Oeste, Riozinho, Irati, PR, Brasil

\author{
$\dagger$ In memoriam \\ Corresponding author: L.O.S. Anjos \\ E-mail: lucianasouza@iac.sp.gov.br
}

Genet. Mol. Res. 15 (4): gmr.15048851

Received June 2, 2016

Accepted June 28, 2016

Published November 21, 2016

DOI http://dx.doi.org/10.4238/gmr.15048851

Copyright $(2016$ The Authors. This is an open-access article distributed under the terms of the Creative Commons Attribution ShareAlike (CC BY-SA) 4.0 License.

\begin{abstract}
Cotesia flavipes (Cameron) is a parasitoid wasp used in the biological control of the sugarcane borer (Diatraea saccharalis) (Fabr., 1794). Studies on the genetic diversity of $C$. flavipes are hampered by the lack of highly polymorphic molecular markers. In this report, a set of 11 microsatellite loci were developed from an enriched library of $C$. flavipes. Four microsatellite loci were polymorphic and were screened in 212 C. flavipes individuals (183 females and 29 males) that were randomly sampled from seven rearing laboratory populations. The number of alleles ranged from two to three. The average inbreeding
\end{abstract}


coefficient $\left(F_{\text {IS }}\right)$ among all laboratory populations was 0.120 , indicating an excess of homozygotes. The average genetic diversity within the laboratory populations was 0.292 , which is lower than the values reported for wild Cotesia spp populations. Genetic diversity was most pronounced within laboratory populations (70 to $90 \%$ ). Most of the observed alleles were fixed or close to fixation. This low overall genetic diversity may have originated from a founder effect, i.e., the contribution of a small number of individuals (genes and alleles) to the formation of these populations. To our knowledge, this study is the first to provide microsatellite loci and an analysis of the genetic structure of $C$. flavipes. Our results suggest that new introductions of $C$. flavipes may increase genetic diversity and improve the efficiency of the biological control of D. saccharalis. In addition, population structure data could be used to estimate the minimum number of wasps to be imported.

Key words: Molecular marker; SSR; Rearing laboratories; Population genetics; Biological control

\section{INTRODUCTION}

Sugarcane is an important crop in Brazil, and this crop has social, economic and environmental impacts. Between the years 2012 and 2013, the area of sugarcane planted in Brazil was estimated at 9.8 million hectares (IBGE, 2013).

The sugarcane borer Diatraea saccharalis (Fabr.) is one of the major causes of sugarcane yield losses. The borer drills a hole at the stem and produces galleries, opening the door for the entry of microorganisms and pathogens that contaminate the broth used in the industry. $D$. saccharalis is widely distributed throughout the continent, being found in North, Central and South America (Cruz, 2007). The borer can be controlled using chemicals, which present a high cost and elevated environmental impact, or biological control agents, which present a lower cost and reduced environmental impact (Bueno, 2009). Cotesia flavipes (Cameron) (Hymenoptera - Braconidae), a parasitic wasp that originated from the Indo-Australian region (Polaszek and Walker, 1991), was introduced from India and Pakistan to Brazil in the 1970s as a biocontrol agent of the sugarcane borer (Botelho et al., 1983; Botelho, 1992). Since its introduction, $C$. flavipes has been produced on a large scale in commercial mills and rearing laboratories (RLs) and plays an important role in controlling this pest in sugarcane cultivation.

The process of mass production of C. flavipes is, briefly, as follows: borers are maintained and replicated in the RL, and some are selected as "prey" for the production of $C$. flavipes. Each borer is subjected to oviposition by only one C. flavipes. The eggs of C. flavipes develop into larvae, which consume the host insect and subsequently form pupae. The pupae form in a tangle of wires referred to as a mass. The pupal masses of borers are removed and placed in plastic cups for later release in the field when C. flavipes emerge. Each released plastic cup of $C$. flavipes contains approximately 1500 individuals on average (Bueno, 2009). The number of $C$. flavipes released in the field is decided based upon on a prior analysis identifying the borer index infestation per hectare and dispersion models (Dinardo-Miranda, 2008; Dinardo-Miranda et al., 2011). The C. flavipes released in the field find and parasitize the borer. The wasps that emerge from the borers can subsequently mate and parasitize other

Genetics and Molecular Research 15 (4): gmr.15048851 
borers; if the wasps are successful, then they repeat this cycle. Thus, field workers who monitor pests such as borers can occasionally find C. flavipes in fields that received wasps released up to a year previously. Although the wasps have adapted to Brazil, they have not adapted to the point of reproducing intensively. The number of wasps that remain in the field is very small, and new wasp masses produced in RLs need to be released. Despite the important role of the wasps, some Brazilian farmers have suggested that there has been a decrease in the efficiency of $C$. flavipes parasitism on D. saccharalis over the years (Dinardo-Miranda, personal communication). This hypothesis is supported by the finding that the activity radius of $C$. flavipes in the field has been decreasing over the years. This radius was reported to be 34 meters in 1980 (Botelho et al., 1980), 25 meters in 2009 (Volpe, 2009) and 15 meters in 2014 (Dinardo-Miranda et al., 2014). On the other hand, in an initial introduction of C. flavipes in maize fields in Kenya, Africa, larvae parasitized by C. flavipes were found at a distance of 64 meters from the release point (Sallam et al., 2001).

This decrease in efficiency may be due to the low genetic variability of $C$. flavipes. This wasp is not native to Brazil, and its introduction occurred over 40 years ago. Although there are no reports indicating the number of mating pairs of $C$. flavipes that were imported (Botelho, 1992), the number is suspected to be small. This situation contrasts with the high biological diversity of the sugarcane borer (Lopes et al., 2014), which is native and is widely distributed throughout the continent. The low diversity of $C$. flavipes could affect behaviors related to the decreased efficiency of parasitism.

The relationship between the efficiency of biological control and genetic variability remains unclear. Baker et al. (2003) suggested that the low genetic variability associated with founder effects may affect the potential for biological control in studies on wasps from the same family as $C$. flavipes.

One practice that is recommended to avoid stagnation and decreases in wasp diversity is periodically exchanging some C. Alavipes individuals among the RL populations. Additionally, reintroduction of $C$. flavipes individuals collected in the field to RLs some days after their release may be beneficial. However, this process is not widely accepted by RLs because it can introduce wasps that may have acquired contamination or disease in the field.

A number of reports have described the biology and behavior of $C$. flavipes in Brazil (Campos-Farinha et al., 2000; Dinardo-Miranda et al., 2014; Volpe et al., 2014). Despite its economical importance and use in applied biological control, little is known about the genetic diversity of $C$. flavipes. Allozyme analysis has revealed $15-36 \%$ polymorphism among populations of C. flavipes from Africa (Omwega and Overholt, 1996; Kimani-Njogu et al., 1998), and mitochondrial DNA analysis of 21 worldwide populations belonging to the $C$. flavipes complex have indicated that geography and recent biological control introductions have had important roles in population structuring, although mtDNA provided little power to differentiate recent biological events (Muirhead et al., 2006). DNA markers have been widely adopted for analyzing the dynamics of plant pest/pathogen populations because of their high levels of precision and accuracy (Milgroom and Peever, 2003). Simple sequence repeats (SSRs) or microsatellite sequences are abundant and evenly distributed in eukaryote genomes (Weising et al., 1995). Where polymorphic loci are available, they can be very useful for genetic diversity and population genetic studies; therefore, the search and development of such genetic markers is warranted. Microsatellite loci are available for several parasitoids, including those in Cotesia, such as C. congregata (Say) (Jensen et al., 2002), C. melitaearum (Wilkinson) (Kankare et al., 2004) and C. sesamiae (Cameron) (Abercrombie et al., 2009),

Genetics and Molecular Research 15 (4): gmr.15048851 
which were successfully tested against their natural populations. Recently, the crossspecies transferability of nine SSRs was demonstrated for Cotesia spp., including $C$. flavipes (Abercrombie et al., 2009); however, to our knowledge, there has been no report of microsatellites developed for the $C$. flavipes genome.

One of the rare study about phylogenic analysis of $C$. flavipes complex, comparing 86 samples from 15 countries, using molecular markers (CO1 and 16S ribosomal RNA gene), grouped C. nonagriae com C. flavipes in a single branch. Furthermore, clades presented in this study reflect the genetic origin of the various introductions in different countries. Moreover, mtDNA and nDNA data show no obvious relationship of Cotesia spp. with their different hosts (Muirhead et al., 2012).

SSRs are usually abundant, polymorphic and neutral. As a co-dominant marker, microsatellite markers are a powerful tool for elucidating the genetic diversity and structure of insect populations. Using SSR markers, the present study aimed to characterize the genetic diversity of seven populations of C. flavipes from commercial RLs and gather information about their genetic structure. This information could be used to devise new management strategies to be applied in RLs to increase genetic diversity levels in wasp populations, which can then be efficiently employed in the biological control of the sugarcane borer. Consequently, the efficiency of parasitism might be improved in an attempt to conduct a type of "breeding" in these parasitoids.

\section{MATERIAL AND METHODS}

\section{SSR-enriched library construction and loci identification}

Because $C$. flavipes is haplodiploid, only females were used in this part of the study. Total DNA was extracted from a pool of 20 wasps (Aljanabi et al., 1999) that were collected from a RL. The Simple Sequence Repeats (SSRs) loci-enriched library was developed using biotinylated oligonucleotide sequences bound to streptavidin-coated magnetic particles (Creste et al., 2006). Briefly, $5 \mathrm{mg}$ of genomic DNA was digested with RsaI, and a sample of 600 ng DNA was ligated to adaptors (Rsa21: 5'CTCTTGCTTACGCGTGGACTA3'; Rsa25 5'TAGTCCACGCGTAAGCAAGAGCACA3'). The ligated fragments were then amplified by polymerase chain reaction (PCR), and the products were allowed to hybridize to biotinylated I5(CT) 8 and I5(GT) 8 probes, which were later recovered by Streptavidin MagneSphere Paramagnetic Particles (Promega - Madison, WI, USA).

The eluted fragments were re-amplified using the Rsa21 primer and cloned into the pGEM-T Easy vector (Promega - Madison, WI, USA). Plasmids were transformed into Escherichia coli XL1-Blue. Positive clones were sequenced using the M13 primer and the BigDye terminator Cycle Sequencing Kit (Applied Biosystems - Foster City, CA, USA) in an ABIPRISM $^{\circledR} 3100$ DNA Analyzer (Applied Biosystems - Foster City, CA, USA).

The sequence analysis for microsatellite (SSR) identification loci was performed using the WEBSAT program (Martins et al., 2009). The search parameters were mono- and di-nucleotides with at least eight repetitions and tri-, tetra-, penta- and hexa-nucleotides with at least four repetitions.

Based on these parameters, primers were designed for 11 microsatellite loci using the program Primer3Plus (Untergasser et al., 2007), and their quality was evaluated using NETPRIMER software (http://www.premierbiosoft.com/netprimer).

Genetics and Molecular Research 15 (4): gmr.15048851 


\section{DNA extraction, PCR conditions and polymorphic loci selection}

An additional 20 C. flavipes female wasps were random sampled from seven RLs (named A to G) located in São Paulo State, Brazil. The seven RLs are from different cities, of which the closest ones are $25 \mathrm{~km}$ apart and the most distant are $258 \mathrm{~km}$ apart.

DNA extraction from unique wasps was achieved as described previously (Lima et al., 2002) with modifications. For each individual sample, $60 \mu \mathrm{L}$ of lysis buffer $(10 \mathrm{mM}$ Tris- $\mathrm{HCl}$, $\mathrm{pH}$ 8.0, $1 \mathrm{mM}$ EDTA, proteinase $\mathrm{K} 60 \mathrm{mg} / \mathrm{mL}$ ) was added. The material was ground with a pestle, and the volume was adjusted to $80 \mu \mathrm{L}$ and incubated at $65^{\circ} \mathrm{C}$ for 20 min followed by $95^{\circ} \mathrm{C}$ for $10 \mathrm{~min}$ and then immediately frozen at $-20^{\circ} \mathrm{C}$ until use.

The eleven primers designed for microsatellite loci, as described above, were tested. The PCR reactions were performed in a final volume of $20 \mu \mathrm{L}$ containing $1 \mathrm{X}$ PCR buffer $\mathrm{KCl}$ (Fermentas $^{\circledR}$ - Waltham, MA, USA), $1.5 \mathrm{mM} \mathrm{MgCl} 2,0.2 \mathrm{mM}$ dNTPs, $0.2 \mu \mathrm{M}$ of each primer, $0.2 \mathrm{U}$ of Taq polymerase and $15 \mathrm{ng}$ of DNA. Amplifications were carried out in a MyCycler thermocycler (Biorad) programmed with a touchdown cycle with an initial step of $95^{\circ} \mathrm{C}$ for $5 \mathrm{~min}$ followed by 10 cycles of $95^{\circ} \mathrm{C}$ for $40 \mathrm{~s}, 65^{\circ} \mathrm{C}$ for $30 \mathrm{~s}$ (decreasing $0.5^{\circ} \mathrm{C}$ per cycle), and $72^{\circ} \mathrm{C}$ for $30 \mathrm{~s}$; followed by 30 cycles of $95^{\circ} \mathrm{C}$ for $40 \mathrm{~s}, 60^{\circ} \mathrm{C}$ for $30 \mathrm{~s}$, and $72^{\circ} \mathrm{C}$ for $30 \mathrm{~s}$; followed by one cycle at $72^{\circ} \mathrm{C}$ for $5 \mathrm{~min}$.

The PCR products were resolved by gel electrophoresis on a $5 \%$ denaturing polyacrylamide gel slab and stained with silver nitrate (Creste et al., 2001).

The heterozygosity and the polymorphic information content (PIC) from the polymorphic loci were performed as described in Nagy et al. (2012).

\section{Molecular and diversity analyses}

A total of 183 female $C$. flavipes were sampled from seven RLs. Each female was removed from an independent pupal mass; i.e., each wasp represents a sample that emerged from a borer that received the oviposition of only one $C$. flavipes.

In addition to the females, 29 males were sampled from the same RLs. Seven of these males were matched with seven females from the same oviposition generation; therefore, these males and females are full siblings (Table 1).

Table 1. Sample numbers of female wasps, males and pairs of full-siblings from the seven sampled rearing laboratories.

\begin{tabular}{l|c|c|c|c|c|c|c|c}
\hline & \multicolumn{9}{|c|}{ Rearing Laboratories } & \multirow{2}{*}{ Total } \\
\cline { 2 - 9 } & A & B & C & D & E & F & G & \\
\hline Female & 19 & 27 & 27 & 27 & 29 & 27 & 27 & 183 \\
\hline Male & 4 & 4 & 5 & 4 & 4 & 4 & 4 & 29 \\
\hline Full-sibling pairs & 1 & 1 & 2 & 0 & 1 & 1 & 1 & 7 \\
\hline
\end{tabular}

DNA extraction was performed as in Lima et al. (2002) with the modifications and amplification conditions described above.

Individual wasps were genotyped to determine the alleles at each of the four SSR polymorphic loci tested (Cot 1, Cot 10, Cot 12 and Cot 17).

Population genetic structure was estimated through Nei's genetic diversity partitioning (Nei, 1973) where $H_{T}$ is the total genetic diversity; $H_{S}$ is the genetic diversity within populations; and $G_{S T}$ is the coefficient of genetic divergence between populations. These parameters were

Genetics and Molecular Research 15 (4): gmr.15048851 
estimated using the software FSTAT (Goudet, 2002). The presence of null alleles was estimated with the software Micro-Checker (version 2.2.3) (Oosterhout et al., 2004). The $G_{S T}$ estimation was standardized according to Nei (1973) and was calculated as follows:

$$
G_{S T}=\frac{H_{T}-H_{S}}{H_{T}}
$$

We also estimated $F_{I S}$, the average coefficient of inbreeding within populations (Wright, 1951), and its equivalent $G_{I S=1-H_{\text {OIHS }}}(\mathrm{Nei}, 1987)$. In addition, we obtained estimates of the expected heterozygosity $\left(H_{\mathrm{E}}\right)$, which is equivalent to $H_{\mathrm{S}}$. Where the data of both sexes were combined, we used weighted averages, with the total number of alleles of each class taken as weights.

Due to the haplodiploid nature of $C$. flavipes, some analysis were performed only in females (SSR loci characterization and Nei's genetic distance), whereas other analyses (allele frequency, diversity of gene loci per population, genetic diversity partitioning) were performed in both sexes.

Although the FSTAT program was developed for diploid individuals, this program allowed us to analyze data from haploid individuals because they are treated as homozygous diploids (Goudet, 1994). In this study, each RL was considered to be a population.

Nei's genetic distance (Nei, 1972) was estimated among the populations using TFPGA software (Miller, 1997) and was visualized using a dendrogram obtained via the UPGMA method using NTSYS software (Rohlf, 2000).

\section{RESULTS}

\section{Microsatellite loci characterization}

From the 96 clones sequenced, 62 (64\%) exhibited SSR sequences. Among these sequences, the dinucleotide (CA)n appeared in $66 \%$ of the sequences, followed by (GA)n in $13 \%$ and $(\mathrm{GC}) \mathrm{n}$ in $10 \%$ of the sequences. The frequencies of the different tri-, tetra- and hexanucleotides were each present at 2 to $3 \%$ in the microsatellite sequences.

From the eleven primers tested, nine were successfully amplified, and four (Cot 1, Cot 10, Cot 12 and Cot 17) were polymorphic in a sample of 20 individuals. The microsatellite loci data are described in Table 2. One primer did not amplify, and another produced unspecific fragments even after several tests (Table 2). The number of alleles per locus was two for both Cot 10 and Cot 12 and three for both Cot 1 and Cot 17. The PIC value ranged from 0.3648 to 0.4514 between the four polymorphic loci (Table 3 ).

The identity of the sequence homology of the C. flavipes microsatellite locus developed in this study was assessed using the Basic Local Alignment Search Tool (BLAST; Altschul et al., 1990). Cot 8 and Cot 12 showed 81 and 90\% of identity, respectively, to the Glyptapanteles indiensis sequence. The sequence of the locus Cot 15 exhibited $93 \%$ identity to C. sesamiae and $86 \%$ to Anastrepha fraterculus. The locus Cot 16 presented $85 \%$ identify to $C$. congregata. The other sequences associated with the loci $\operatorname{Cot} 1, \operatorname{Cot} 7, \operatorname{Cot} 9, \operatorname{Cot} 10, \operatorname{Cot}$ 13 and Cot 17 were unique and did not align to other sequences.

Genetics and Molecular Research 15 (4): gmr.15048851 
Table 2. Description of microsatellite loci of Cotesia flavipes: locus ID, repeat motif, primer sequence, expected fragment size (EFS) (bp-base pair), microsatellite sequence GenBank accession number, and PCR result.

\begin{tabular}{|c|c|c|c|c|c|}
\hline Locus ID & Repeat motif & Primer Sequence $\left(5^{\prime}-3^{\prime}\right)$ & EFS (bp) & GenBank No. & PCR result \\
\hline Cot 1 & (CT)13 & $\begin{array}{l}\text { F: AAAGGTCCCGATTGGAGAAT } \\
\text { R: TTGCCTTGTCAAACCACTCA }\end{array}$ & 176 & KJ124563 & Polymorphic \\
\hline $\operatorname{Cot} 5$ & (TG)29 & $\begin{array}{l}\text { F: TGAAGGTCACAGAAAACTTACAT } \\
\text { R: TATCGGAATCGGTCAAAAT }\end{array}$ & 213 & KJ124564 & No fragment \\
\hline $\operatorname{Cot} 7$ & (GT)18 & $\begin{array}{l}\text { F: TGACTACCCCCGCAAGTTT } \\
\text { R: TTGAAATCTATCCCTCTGAATCG }\end{array}$ & 188 & KJ124565 & Monomorphic \\
\hline $\operatorname{Cot} 8$ & $\begin{array}{c}\text { (AC) } 22 \\
\text { (CG) } 8\end{array}$ & $\begin{array}{l}\text { F: TTGTCCAAATCGGTTCAAAA } \\
\text { R: CGAGGGTTCCTGAGAGAGTG }\end{array}$ & 212 & KJ124566 & Monomorphic \\
\hline $\operatorname{Cot} 9$ & (GCAT)4 & $\begin{array}{l}\text { F: TGTGTATCTGTGGGGAGGTG } \\
\text { R: CGGACCGTTACATCGTTAGC }\end{array}$ & 209 & KJ124567 & Monomorphic \\
\hline $\operatorname{Cot} 10$ & $\begin{array}{l}\text { (ATA)6 } \\
\text { (A) } 10\end{array}$ & $\begin{array}{l}\text { F: GTGACACCCTCCGCTAAAAA } \\
\text { R: AGGTTTTGTGTTCTTGCTTGC }\end{array}$ & 244 & KJ124568 & Polymorphic \\
\hline Cot 12 & (GT)14 & $\begin{array}{l}\text { F: CTCAGTCCCAACTCGTATGC } \\
\text { R: TGATGTCACTGGTTGTCCTTTC }\end{array}$ & 196 & KJ124569 & Polymorphic \\
\hline Cot 13 & $(\mathrm{GAC}) 5$ & $\begin{array}{l}\text { F: ACTTGCACACACCCACACAC } \\
\text { R: GCTGACGGGCAGACTATTTT }\end{array}$ & 227 & KJ124570 & Monomorphic \\
\hline Cot 15 & (GT)22 & $\begin{array}{l}\text { F: CTTCGGAGAGTGAGGTGGAG } \\
\text { R: CTGTTATCGGGAGCAGAGGT }\end{array}$ & 186 & KJ124571 & Monomorphic \\
\hline Cot 16 & (AC) 29 & $\begin{array}{l}\text { F: TTTGTAAAGCCCTTGCGAAT } \\
\text { R: TGGTTTCACCCTGTTTTTCG }\end{array}$ & 241 & KJ124572 & $\begin{array}{l}\text { Unspecific } \\
\text { fragment(s) }\end{array}$ \\
\hline Cot 17 & (TTTTAT)4 & $\begin{array}{l}\text { F: TCCGGCAAATGTCTATCGTA } \\
\text { R: TTGCCTCATTTATGCACCAC }\end{array}$ & 238 & KJ124563 & Polymorphic \\
\hline
\end{tabular}

Table 3. Characterization of microsatellite loci of Cotesia flavipes: locus ID, size range observed (SRO) (bpbase pair), observed number of alleles $(\mathrm{N})$, heterozygosity $(\mathrm{H})$, and polymorphic information content (PIC).

\begin{tabular}{l|l|l|l|l}
\hline Locus ID & SRO (bp) & N & H & PIC \\
\hline $\operatorname{Cot} 1$ & $180-186$ & 3 & 0.5064 & 0.4514 \\
\hline $\operatorname{Cot} 10$ & $248-252$ & 2 & 0.4888 & 0.3693 \\
\hline $\operatorname{Cot} 12$ & $200-204$ & 2 & 0.4800 & 0.3648 \\
\hline $\operatorname{Cot} 17$ & $240-246$ & 3 & 0.5288 & 0.4475 \\
\hline
\end{tabular}

\section{Allele frequency}

The frequency of alleles at the four polymorphic loci analyzed in the seven studied RLs is described in Table 4. In females, two loci (Cot 1 and Cot 17) showed the existence of fixed alleles and/or alleles close to fixation in some RLs. In RLs B and F, the frequency of the Cot 1.1 allele was 1.0, and the same frequency was observed in RL E for the Cot 17.1 allele. In contrast, some alleles, such as Cot 17.2, showed a low frequency in many RL populations, including those from laboratories E, F and G. The Cot 1.2 allele was observed only in populations from RLs E and G; the Cot 1.3 allele was only found in populations from RLs A, C and D; and Cot 17.3 was detected only in populations from RLs B and G. Among the males, the four loci tested in 29 individuals exhibited only two alleles, and the Cot 1.2 and Cot 17.3 alleles were not found in any of the samples analyzed.

\section{Partitioning of genetic diversity}

In the 183 females tested, the expected heterozygosity ranged from 0.145 to 0.415 (mean 0.292), while the observed heterozygosity ranged from 0.053 to 0.421 (mean 0.257 ) (Table 5).

The average inbreeding coefficient $\left(F_{\text {IS }}\right)$ was 0.120 , which indicates homozygous excess. An analysis using the program Micro-Checker identified the possible presence of a null allele at the Cot 1 locus. 
Table 4. Allele frequencies observed among the seven tested rearing laboratories for female and male wasps. $\mathrm{N}$ - number of wasps with scorable alleles.

\begin{tabular}{|c|c|c|c|c|c|c|c|}
\hline & \multicolumn{7}{|c|}{ Rearing Laboratories } \\
\hline & $\mathrm{A}$ & $\mathrm{B}$ & $\mathrm{C}$ & $\mathrm{D}$ & $\mathrm{E}$ & $\mathrm{F}$ & $\mathrm{G}$ \\
\hline \multicolumn{8}{|l|}{ Females } \\
\hline $\mathrm{N}$ & 19 & 27 & 27 & 27 & 27 & 27 & 27 \\
\hline Cot 1.1 & 0.842 & 1.000 & 0.963 & 0.852 & 0.889 & 1.000 & 0.889 \\
\hline Cot 1.2 & 0 & 0 & 0 & 0 & 0.111 & 0 & 0.111 \\
\hline Cot 1.3 & 0.158 & 0 & 0.037 & 0.148 & 0 & 0 & 0 \\
\hline $\mathrm{N}$ & 18 & 27 & 25 & 21 & 25 & 26 & 25 \\
\hline Cot 10.1 & 0.861 & 0.833 & 0.780 & 0.786 & 0.180 & 0.442 & 0.540 \\
\hline Cot 10.2 & 0.139 & 0.167 & 0.220 & 0.214 & 0.820 & 0.558 & 0.460 \\
\hline $\mathrm{N}$ & 19 & 27 & 27 & 27 & 29 & 27 & 27 \\
\hline Cot 12.1 & 0.842 & 0.556 & 0.759 & 0.796 & 0.672 & 0.556 & 0.630 \\
\hline Cot 12.2 & 0.158 & 0.444 & 0.241 & 0.204 & 0.328 & 0.444 & 0.370 \\
\hline $\mathrm{N}$ & 19 & 27 & 27 & 27 & 29 & 27 & 26 \\
\hline Cot 17.1 & 0.789 & 0.815 & 0.815 & 0.704 & 1.000 & 0.963 & 0.865 \\
\hline Cot 17.2 & 0.211 & 0.111 & 0.185 & 0.296 & 0 & 0.037 & 0.058 \\
\hline Cot 17.3 & 0 & 0.074 & 0 & 0 & 0 & 0 & 0.077 \\
\hline \multicolumn{8}{|l|}{ Males } \\
\hline $\mathrm{N}$ & 4 & 4 & 5 & 4 & 4 & 4 & 4 \\
\hline Cot 1.1 & 1.000 & 1.000 & 1.000 & 0.750 & 1.000 & 1.000 & 0.750 \\
\hline Cot 1.2 & 0 & 0 & 0 & 0 & 0 & 0 & 0 \\
\hline Cot 1.3 & 0 & 0 & 0 & 0.250 & 0 & 0 & 0.250 \\
\hline $\mathrm{N}$ & 3 & 4 & 2 & 3 & 3 & 4 & 4 \\
\hline Cot 10.1 & 0.667 & 0.500 & 1.000 & 1.000 & 0 & 0 & 0.500 \\
\hline Cot 10.2 & 0.333 & 0.500 & 0 & 0 & 1.000 & 1.000 & 0.500 \\
\hline $\mathrm{N}$ & 3 & 3 & 3 & 2 & 2 & 2 & 2 \\
\hline Cot 12.1 & 0.667 & 0.667 & 1.000 & 1.000 & 1.000 & 0 & 0.500 \\
\hline Cot 12.2 & 0.333 & 0.333 & 0 & 0 & 0 & 1.000 & 0.500 \\
\hline $\mathrm{N}$ & 3 & 2 & 4 & 3 & 4 & 4 & 3 \\
\hline Cot 17.1 & 1.000 & 1.000 & 1.000 & 0.333 & 1.000 & 1.000 & 0.333 \\
\hline Cot 17.2 & 0 & 0 & 0 & 0.667 & 0 & 0 & 0.667 \\
\hline Cot 17.3 & 0 & 0 & 0 & 0 & 0 & 0 & 0 \\
\hline
\end{tabular}

Table 5. Characterization of microsatellite loci of Cotesia flavipes: loci ID, repeat motif, size range (bpbase pair), observed number of alleles $(\mathrm{N})$, observed heterozygosity $\left(H_{\mathrm{O}}\right)$, expected heterozygosity $\left(H_{\mathrm{E}}\right)$, and fixation index $\left(F_{\text {IS }}\right)$. Data are from females only.

\begin{tabular}{l|c|c|c|c|c|c}
\hline Loci ID & Repeat motif & Size range $(\mathrm{bp})$ & $\mathrm{N}$ & $H_{\mathrm{O}}$ & $H_{\mathrm{E}}$ & $F_{\text {IS }}$ \\
\hline $\operatorname{Cot} 1$ & $(\mathrm{CT})_{13}$ & $180-186$ & 3 & 0.053 & 0.145 & 0.636 \\
\hline $\operatorname{Cot} 10$ & $(\mathrm{ATA})_{6}(\mathrm{~A})_{10}$ & $248-252$ & 2 & 0.333 & 0.363 & 0.082 \\
\hline $\operatorname{Cot} 12$ & $(\mathrm{GT})_{14}$ & $200-204$ & 2 & 0.421 & 0.415 & -0.015 \\
\hline $\operatorname{Cot} 17$ & (TTTTAT $_{4}$ & $240-246$ & 3 & 0.221 & 0.246 & 0.100 \\
\hline
\end{tabular}

The total average genetic diversity $\left(H_{\mathrm{T}}\right)$ in the 29 tested males was 0.354 , and the average genetic diversity within an $\mathrm{RL}\left(H_{\mathrm{S}}\right)$ was 0.245 . The $G_{\mathrm{ST}}$ value was 0.308 . Comparative data between females and males are shown in Table 6.

Table 6. Diversity measures in the population studied: $H_{\mathrm{T}}$ (total diversity), $H_{\mathrm{S}}$ (diversity within populations), $D_{\mathrm{ST}}$ (diversity among populations), $G_{\mathrm{ST}}$ (coefficient of genetic divergence between populations), $G_{\mathrm{ST}}{ }^{\text {' }}\left(G_{\mathrm{ST}}\right.$ corrected for sample size), $F_{\text {IS }}$ (inbreeding coefficient).

\begin{tabular}{l|c|c|c|c|c|c}
\hline Group & $H_{\mathrm{T}}$ & $H_{\mathrm{S}}$ & $D_{\mathrm{ST}}$ & $G_{\mathrm{ST}}$ & $G_{\mathrm{ST}}$ & $F_{\text {IS }}$ \\
\hline Female & 0.328 & 0.292 & 0.035 & 0.108 & 0.124 & 0.120 \\
\hline Male & 0.354 & 0.245 & 0.109 & 0.308 & 0.342 & - \\
\hline Weighted average & 0.330 & 0.289 & 0.040 & 0.122 & 0.140 & - \\
\hline
\end{tabular}

Genetics and Molecular Research 15 (4): gmr.15048851 


\section{Gene diversity}

The genetic diversity per locus per RL in the male and female populations was analyzed. The highest average diversity was found in laboratory G, followed by D, A, B and C (B and $\mathrm{C}$ showed equal levels of diversity), $\mathrm{F}$ and finally, $\mathrm{E}$ (Table 7). The dendrogram based on Nei's genetic distance separated the populations into two clusters (Figure 1).

Table 7. Diversity in gene loci per population of female and male wasps. Averages of the seven sampled rearing laboratories are presented.

\begin{tabular}{l|l|c|c|c|c|c|c|c}
\hline \multirow{2}{*}{} & \multicolumn{2}{l}{ Loci } & \multicolumn{6}{c}{ Rearing Laboratories } \\
\cline { 3 - 9 } & & $\mathrm{A}$ & $\mathrm{B}$ & $\mathrm{C}$ & $\mathrm{D}$ & $\mathrm{E}$ & $\mathrm{F}$ & $\mathrm{G}$ \\
\hline \multirow{3}{*}{ Females N=183 } & Cot 1 & 0.281 & 0 & 0.074 & 0.262 & 0.202 & 0 & 0.201 \\
\cline { 2 - 9 } & Cot 10 & 0.248 & 0.282 & 0.352 & 0.345 & 0.302 & 0.503 & 0.508 \\
\cline { 2 - 9 } & Cot 12 & 0.275 & 0.499 & 0.373 & 0.330 & 0.447 & 0.506 & 0.476 \\
\cline { 2 - 9 } & Cot 17 & 0.342 & 0.325 & 0.308 & 0.427 & 0 & 0.073 & 0.246 \\
\cline { 2 - 9 } & Average & 0.287 & 0.277 & 0.277 & 0.341 & 0.238 & 0.271 & 0.358 \\
\cline { 2 - 9 } & Standard deviation & 0.040 & 0.207 & 0.138 & 0.068 & 0.188 & 0.272 & 0.157 \\
\hline Males N=29 & Average & 0.333 & 0.333 & 0 & 0.292 & 0 & 0 & 0.708 \\
\hline
\end{tabular}

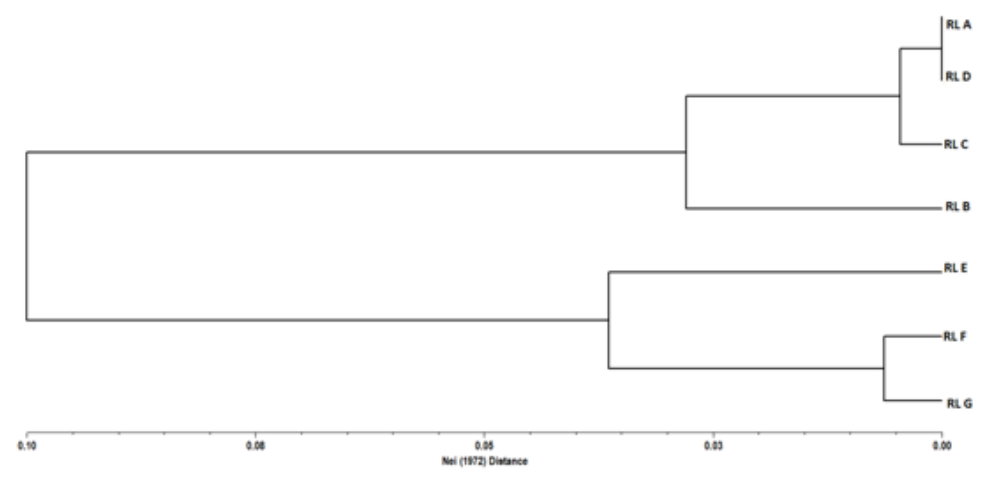

Figure 1. Dendrogram based on Nei's distance obtained from microsatellite markers screened among seven $C$. flavipes rearing laboratory (RL) populations (A to G).

The first cluster included the populations derived from RLs A, D, C and B (Figure 1), and the second cluster comprised the populations derived from RLs F, G and E. The highest identity was observed between RLs A and D (0.9954), and the lowest identity was observed between RLs A and E (0.8136) (Table 8).

Table 8. Nei's genetic distances (1972) (below the diagonal) and identity (above the diagonal) among female wasps from the seven rearing laboratories studied.

\begin{tabular}{l|c|c|c|c|c|c|c}
\hline Rearing Laboratories & $\mathrm{A}$ & $\mathrm{B}$ & $\mathrm{C}$ & $\mathrm{D}$ & $\mathrm{E}$ & $\mathrm{F}$ & $\mathrm{G}$ \\
\hline $\mathrm{A}$ & $* * * *$ & 0.9601 & 0.9901 & 0.9954 & 0.8136 & 0.8930 & 0.9339 \\
\hline $\mathrm{B}$ & 0.0407 & $* * * *$ & 0.9824 & 0.9621 & 0.8400 & 0.9421 & 0.9628 \\
\hline $\mathrm{C}$ & 0.0099 & 0.0177 & $* * * *$ & 0.9916 & 0.8628 & 0.9390 & 0.9667 \\
\hline $\mathrm{D}$ & 0.0047 & 0.0386 & 0.0084 & $* * * *$ & 0.8319 & 0.9066 & 0.9429 \\
\hline $\mathrm{E}$ & 0.2063 & 0.1743 & 0.1476 & 0.1840 & $* * * *$ & 0.9682 & 0.9520 \\
\hline $\mathrm{F}$ & 0.1132 & 0.0596 & 0.0630 & 0.0981 & 0.0323 & $* * * *$ & 0.9892 \\
\hline
\end{tabular}

Genetics and Molecular Research 15 (4): gmr.15048851 
The clustering analysis suggested that the exchange of wasps was most intensive between RLs A and D, followed by RLs C and B. On the other branch, the greatest number of wasps may have been exchanged between RLs F and G, followed by RL E.

The Cot 1.3 allele is present only on the branch comprising RLs A, D and C, although this allele was also observed in one male from each of RLs D and G (Figure 1 and Table 4). Cot 17.2 occurred at a low frequency on the branch comprised of RLs E, F and G, in fact, this allele was not detected in RL E (Figure 1 and Table 4).

\section{DISCUSSION}

In studies on $C$. flavipes using allozymes, the frequency of monomorphic loci has been reported to be high, at 85 or 64\% (Omwega and Overholt, 1996; and Kimani-Njogu et al., 1998). Both studies were performed using wasps collected in Africa, a continent where $C$. flavipes was introduced several times in different countries for biological control. In this study, we observed a frequency of monomorphic loci of $55 \%$ for microsatellite markers developed from an enriched C. flavipes genomic library in samples from RLs, suggesting low genetic diversity in this artificial population. Note that microsatellites tend to be more variable than are allozymes.

C. flavipes is not originally from the Americas but the wasps were introduced in Brazil in the 1970s from India and Pakistan for biological control of the sugarcane borer (Botelho, 1992). No reintroductions of C. flavipes have been made since the original introduction in the 1970s. This species has been mass-reared and released for decades as it is highly successful in controlling the sugarcane borer, but there are no reports of the establishment of this species in the field. Thus, the individuals sampled in this study were produced for use in the field and may not be representative of a natural or native population in the countries where $C$. flavipes originated. Thus, loci that were monomorphic in the sample analyzed may yield different results if tested in larger populations or in native or sister species samples, which are heterogeneous populations.

In the RL populations, only two alleles were observed in males, and a maximum of three alleles were observed in females. In addition to the 29 male wasps, the results distributed among the RLs also indicated a low number of alleles (Table 4). Furthermore, despite the difference in the number of females and males tested, some alleles were found only in females (Cot 1.2 and Cot 17.3), suggesting the possibility of the existence of exclusive alleles in this sex in C. flavipes (Table 4).

In a study examining natural populations of six species of Cotesia spp., the number of alleles was found to range from 1 to 25 (Kankare et al., 2004), whereas it ranged from 1 to 14 in C. sesamiae (Abercrombie et al., 2009). We do not know whether the low number of alleles is a natural feature of $C$. flavipes, a characteristic of the wasps produced in this country, or is due to differences in the applied methodologies between the present report and previous studies.

In this study, the observed heterozygosity in C. flavipes ranged from 0.053 to 0.421 (mean 0.257), consistent with the mean levels found in C. congregata (0.312), C. melitaearum (0.30) and C. sesamiae (0.39) (Jensen et al., 2002; Kankare et al., 2004; Abercrombie et al., 2009), respectively. Thus, in studies on Cotesia spp, the average observed heterozygosity is near these values. However, the genetic diversity within the $C$. flavipes RLs was lower on average $(0.292$ for females) than the values of $0.458,0.6$ and 0.5 reported in the literature for C. congregata, $C$. melitaearum and C. sesamiae (Jensen et al., 2002; Kankare et al., 2004; Abercrombie et al., 2009),

Genetics and Molecular Research 15 (4): gmr.15048851 
respectively.

According to Nei's genetic diversity partitioning, the proportion of the total genetic diversity distributed in females among the laboratory populations was $10.8 \%\left(G_{\mathrm{ST}}=0.108\right)$, while within the laboratory populations, it was $89.2 \%$. In males, the diversity between the laboratory populations was $30.8 \%\left(G_{\mathrm{ST}}=0.308\right)$, and within the laboratory populations, it was $69.2 \%$. To our knowledge, information on the genetic population structure of $C$. flavipes, including its natural populations, is lacking, which makes comparison of our results difficult. However, the obtained $G_{\mathrm{ST}}$ value for females and males, which is a measure of divergence among populations, was higher than the analogous $F_{\mathrm{ST}}$ value of 0.032 reported for natural populations of $C$. glomerata (Elias et al., 2010), suggesting that the artificial wasp populations from different laboratories are becoming divergent and that little or no exchange is being conducted among these laboratories. Nevertheless, the $G_{\mathrm{ST}}$ value was lower than that reported for natural populations of Diaeretiella rapae (another parasitoid wasp), which was evaluated in four countries from different continents (Baker et al., 2003).

The high frequency of fixed alleles, rare alleles and alleles at low frequencies, together with the low number of alleles observed per locus, reinforces the conclusion that the exchange of wasps among RLs is lacking or is not sufficiently efficient to maintain the genetic diversity of the artificially produced wasps in laboratories. Additionally, a founder effect (i.e., the establishment of a new population by a small number of individuals) may have contributed to the low overall diversity observed here. In fact, according to personal communications, the first introductions of $C$. flavipes in Brazil were performed using a very small number of wasp breeding pairs. According to Omwega and Overholt (1996), 1000 breeding females of $C$. flavipes are necessary to prevent the rapid decay of heterozygosity in the wasp colonies, and this number is greater than the estimated number of individuals introduced to begin the largescale production of $C$. flavipes in Brazil.

Moreover, according to Botelho (1992), the first introduced C. flavipes (formerly Apanteles flavipes) showed the greatest adaptation to Brazilian conditions and overcame native parasitoid populations to control the sugarcane borer, even in areas without a mass release of C. flavipes. It is possible that over the years, the laboratories may have unintentionally selected less adaptive and less competitive wasps.

C. flavipes exhibits genetic variation in association with different hosts and geographical barriers (Muirhead et al., 2006). As such, C. flavipes may exhibit different behavior when confronted with $D$. saccharalis used for reproduction at the RLs versus $D$. saccharalis subjected to control in the field. In addition, the RLs can serve as geographical barriers if there is no exchange of $C$. flavipes among them, subsequently decreasing genetic diversity within RLs.

The presence of infertile diploid males in the Hymenoptera is related to a decrease in the diversity of the group. C. flavipes diploid males are observed more frequently in populations showing a rapid loss of heterozygosity in comparison with those displaying a slower loss of heterozygosity (Omwega and Overholt, 1996). In contrast, the presence of fertile diploid $C$. glomerata males (Elias et al., 2010) reduces the negative impact of inbreeding. In this study, no diploid males were identified, although the number of males analyzed was lower (29) than the number of females (183).

Some RLs have adopted different management strategies regarding feeding, the choice of reproductive wasps or other aspects for the reproduction of C. flavipes (Veiga et al., 2013). Such strategies may be related to morphological differences, the sex ratio, developmental stages

Genetics and Molecular Research 15 (4): gmr.15048851 
and longevity. These patterns are likely associated with the genetic differences in the wasps from each RL, and these strategies may also be linked to the maintenance of certain alleles.

In addition to the differences in wasp management among the laboratories (Veiga et al., 2013), wasps collected in the field days after their release should be incorporated into the RL populations and used in the mating of subsequent generations. This practice appears to not to be occurring efficiently. Perhaps the RL populations showing the greatest diversity are those that apply these rules more often than others, although there is no detailed information about mass production in these RLs.

The diversity studies that have been carried out on C. flavipes wasp RL populations in Brazil have been criticized. However, high inbreeding can cause low diversity, and the data presented here suggest the existence of low genetic diversity levels in the laboratory populations as a whole. However, among the seven evaluated RLs, the laboratory populations that showed greater diversity likely correspond to those that are exchanging and reintroducing wasps more frequently than the other laboratories. This management strategy can decrease the rate of inbreeding and increase genetic diversity, reflecting an improvement of the efficiency of the control of $D$. saccharalis. Importantly, genetic drift and selection are more intensified in small populations and can lead to the fixation of both favorable and unfavorable alleles.

São Paulo State, in the southeast region, is the major sugarcane-producing state in Brazil. The agro-industry, including the RLs of C. flavipes production, is also highly developed in this state. The C. flavipes RLs located in São Paulo State export wasps for sugar fields in other Brazilian federal states and regions. Although this represents a broad area of $C$. flavipes control activity, it is unknown whether wasp parasitism efficiency varies among Brazilian states or regions.

One suggested strategy to improve the efficiency of biological control in our country is the import of new C. flavipes mating pairs to increase the diversity and parasitism capacity of the wasp populations. We can use the information on the existing population structure to consider the introduction of new germplasm and to determine which countries are best to import from and the minimum number of wasps to be imported.

To our knowledge, this study is the first to describe the genetic structure of artificial populations of $C$. flavipes derived from RLs. Our initial findings confirmed the hypothesis of low overall genetic diversity, with most of the genetic diversity (70 to 90\%) existing within the RLs.

Consideration of the allozyme and SSR information gives rise to the hypothesis that C. flavipes is a species that naturally exhibits low levels of diversity. However, C. flavipes reproduces naturally, indicating that it is adaptable despite its low diversity. This fact requires that extra attention be paid to isolated populations of $C$. flavipes, such as the populations in RLs.

In general, $C$. flavipes is described as a low-diversity species, presenting many fixed alleles when studied using allozymes (Omwega and Overholt, 1996; Kimani-Njogu et al., 1998). This low diversity may affect the capacity of the wasps to parasitize the sugarcane borer, as this ability has diminished since the introduction of $C$. flavipes into Brazil. Thus, the findings and discussion presented in this report suggest the reintroduction of new mating pairs of $C$. flavipes from countries where these insects are native (origin center) as a strategy to increase diversity and improve biological control. In addition, attention must be given by RLs to compliance with management strategies, including the exchange of wasp matrices and reintroduction of wasps collected in the field to maintain adequate genetic diversity levels among the wasps that are produced.

The importance of the present study lies in the economic and environmental impact

Genetics and Molecular Research 15 (4): gmr.15048851 
of borer control by sugarcane farmers. This form of biological control leads to improvements with a low cost and low environmental impact, guaranteeing the sustainability of the sugar and ethanol industry in the country.

\section{Conflicts of interest}

The authors declare no conflict of interest.

\section{ACKNOWLEDGMENTS}

Research supported by a grant (\#2008/56146-5) and fellowships from the Fundação de Amparo à Pesquisa do Estado de São Paulo (FAPESP).

\section{REFERENCES}

Abercrombie LG, Anderson CM, Baldwin BG, Bang IC, et al.; Molecular Ecology Resources Primer Development Consortium (2009). Isolation and characterization of nine microsatellite loci in Cotesia sesamiae (Cameron) (Hymenoptera: Braconidae), a parasitoid of African stem borer pests. In: Molecular Ecology Resources Primer Development Consortium. Permanent Genetic Resources added to Molecular Ecology Resources database 1 January 2009-30 April 2009. Mol. Ecol. Resour. 9: 1375-1379.

Aljanabi SM, Forget L and Dookun A (1999). An improved and rapid protocol for the isolation of polysaccharide and polyphenol-free sugarcane DNA. Plant Mol. Biol. Report. 17: 1-8. http://dx.doi.org/10.1023/A:1007692929505

Altschul SF, Gish W, Miller W, Myers EW, et al. (1990). Basic local alignment search tool. J. Mol. Biol. 215: 403-410.

Baker DA, Loxdale HD and Edwards OR (2003). Genetic variation and founder effects in the parasitoid wasp, Diaeretiella rapae (M'intosh) (Hymenoptera: Braconidae: Aphidiidae), affecting its potential as a biological control agent. Mol. Ecol. 12: 3303-3311.http://dx.doi.org/10.1046/j.1365-294X.2003.02010.x

Botelho PSM (1992). Quinze anos de controle biológico da Diatraea saccharalis utilizando parasitoides. Pesq. Agrop. Brasil 27: 255-262.

Botelho PSM, Macedo N and Mendes AC (1980). Aspects of the population dynamics of Apanteles flavipes (Cameron) and support capacity of its host Diatraea saccharalis (Fabr.). In: Congress of the International Society of Sugar Cane Technologists - ISSCT, Manila, Philippines. 2: 1736-1745.

Botelho PSM, De Gaspari N, Macedo N, Almeida LC, et al. (1983). Control of Diatraea saccharalis with Apanteles flavipes. Proc. Congr. Int. Soc. Sugar Cane Technol. 2: 926-933.

Bueno VHP (2009). Controle biológico de pragas - produção massal e controle de qualidade. (2nd. Eds.) Eds. UFLA, Lavras, (in Portuguese).

Campos-Farinha AEC, Chaud-Netto J and Gobbi N (2000). Biologia reprodutiva de Cotesia flavipes (Cameron) (Hymenoptera: Braconidae), discriminação entre lagartas parasitadas e não parasitadas de Diatraea saccharalis (Fabricius) (Lepidoptera: Pyralidae), tempo de desenvolvimento e razão sexual dos parasitoides. Arq. Inst. Biol. (Sao Paulo) 67: 229-234.

Creste S, Tulmann Neto A and Figueira A (2001). Detection of single sequence repeat polymorphisms in denaturing polyacrylamide sequencing gels by silver staining. Plant Mol. Biol. Report. 19: 299-306. http://dx.doi.org/10.1007/ BF02772828

Creste S, Benatti TR, Orsi MR, Risterucci AM, et al. (2006). Isolation and characterization of microsatellite loci from a commercial cultivar of Musa acuminata. Mol. Ecol. Notes 6: 303-306. http://dx.doi.org/10.1111/j.1471$\underline{8286.2005 .01209 . x}$

Cruz I (2007). A Broca da Cana-de-Açúcar, Diatraea saccharalis, em Milho, no Brasil, Circular Técnica, Embrapa. Available at [http://cnpms.embrapa.br/publicacoes/publica/2007/circular/Circ 90.pdf]

Dinardo-Miranda LL (2008). Pragas. In: Cana-de-açúcar. (Dinardo-Miranda LL, Vasconcelos ACM, Landell MGA, eds.). Instituto Agronômico, Campinas, 349-404. (in Portuguese).

Dinardo-Miranda LL, Fracasso JV and Perecin D (2011). Spatial variability of populations of Diatraea saccharalis in sugarcane fields and suggestion of sampling method. Bragantia 70: 577-585. http://dx.doi.org/10.1590/S0006$\underline{87052011005000008}$

Dinardo-Miranda LL, Fracasso JV, Costa VP and Lopes DOT (2014). Dispersal of Cotesia flavipes in sugarcane field and implications for parasitoid releases. Bragantia 73: 163-170. http://dx.doi.org/10.1590/brag.2014.023

Genetics and Molecular Research 15 (4): gmr.15048851 
Elias J, Dorn S and Mazzi D (2010). Inbreeding in a natural population of the gregarious parasitoid wasp Cotesia glomerata. Mol. Ecol. 19: 2336-2345.http://dx.doi.org/10.1111/j.1365-294X.2010.04645.x

Goudet J (1994). FSTAT, a program for IBM PC compatibles to calculate Weir and Cockerham's (1984) estimators of F-statistics. (Version 1.2). Available at [http://www.ibrarian.net/navon/paper/FSTAT_a program_for_IBM_PC compatibles to calcul.pdf?paperid $=15794910]$.

Goudet J (2002). FSTAT, a program to estimate and test gene diversities and fixation indices. (Version 2.9.3). Available at [http://www2.unil.ch/popgen/softwares/fstat.htm].

IBGE (2013). Instituto Brasileiro de Geografia e Estatística. Available at [http://www.ibge.gov.br/home/estastistica/ indicadores/agropecuaria/lspa/lspa_201302.pdf]. Accessed December 15, 2014. (in Portuguese).

Jensen MK, Kester KM, Kankare M and Brown BL (2002). Characterization of microsatellite loci in the parasitoid, Cotesia congregata (Say) (Hymenoptera: Braconidae). Mol. Ecol. Notes 2: 346-348. http://dx.doi.org/10.1046/ j.1471-8286.2002.00246.x

Kankare M, Jensen MK, Kester KM and Saccheri IJ (2004). Characterization of microsatellite loci in two primary parasitoids of the butterfly Melitaea cinxia, Cotesia melitaearum and Hyposoter horticola (Hymenoptera). Mol. Ecol. Notes 4: 231-233. http://dx.doi.org/10.1111/j.1471-8286.2004.00626.x

Kimani-Njogu SW, Overholt WA, Woolley JB and Omwega CO (1998). Electrophoretic and phylogenetic analyses of selected allopatric populations of the Cotesia flavipes complex (Hymenoptera: Braconidae), parasitoids of cereal stemborers. Biochem. Syst. Ecol. 26: 285-296. http://dx.doi.org/10.1016/S0305-1978(97)00108-7

Lima LHC, Campos L, Moretzsohn MC, Návia D, et al. (2002). Genetic diversity of Bemisia tabaci (Genn.) Populations in Brazil revealed by RAPD markers. Genet. Mol. Biol. 25: 217-223. http://dx.doi.org/10.1590/S1415$\underline{47572002000200016}$

Lopes DA, Cantagalli LB and Stuchi ALP Barateiro, Mangolin CA, et al. (2014). Population genetics of the sugarcane borer Diatraea saccharalis (Fabr.) (Lepidoptera: Crambidae). Acta Sci. Agron. Maringá. 36: 189-194.

Martins WS, Lucas DCS, Neves KFS and Bertioli DJ (2009). WebSat-a web software for microsatellite marker development. Bioinformation 3: 282-283. http://dx.doi.org/10.6026/97320630003282

Milgroom MG and Peever TL (2003). Population biology of plant pathogens. Plant Dis. 87: 608-617. http://dx.doi. org/10.1094/PDIS.2003.87.6.608

Miller MP (1997). Tools for Population Genetic Analysis (TFPGA), Version 1.3: A Windows Program for Analysis of Allozyme and Molecular Population Genetic Data, University of Northem Arizona, Flagstaff, Ariz, USA.

Muirhead KA, Murphy NP, Sallam MN, Donnellan SC, et al. (2006). Mitochondrial DNA phylogeography of the Cotesia flavipes complex of parasitic wasps (Hymenoptera: Braconidae). Ann. Soc. Entomol. Fr. 42: 309-318. http://dx.doi. org/10.1080/00379271.2006.10697462

Muirhead KA, Murphy NP, Sallam N, Donnellan SC, et al. (2012). Phylogenetics and genetic diversity of the Cotesia flavipes complex of parasitoid wasps (Hymenoptera: Braconidae), biological control agents of lepidopteran stemborers. Mol. Phylogenet. Evol. 63: 904-914.http://dx.doi.org/10.1016/j.ympev.2012.03.003

Nagy S, Poczai P, Cernák I, Gorji AM, et al. (2012). PICcalc: an online program to calculate polymorphic information content for molecular genetic studies. Biochem. Genet. 50: 670-672. http://dx.doi.org/10.1007/s10528-012-9509-1

Nei M (1972). Genetic distance between populations. Am. Nat. 106: 283-292. http://dx.doi.org/10.1086/282771

Nei M (1973). Analysis of gene diversity in subdivided populations. Proc. Natl. Acad. Sci. USA 70: 3321-3323. http:// dx.doi.org/10.1073/pnas.70.12.3321

Nei M (1987). Genes in populations. In: Molecular Evolutionary Genetics. Columbia University Press, New York, 164-165.

Omwega CO and Overholt WA (1996). Genetic changes occurring during laboratory rearing of Cotesia flaripes Cameron (Hymenoptera: Braconidae), an imported parasitoid for the control of gramineous stem borers in Africa. Afr. Entomol. 4: 231-237.

Oosterhout CV, Hutchinson WF, Wills DPM and Shipley P (2004). MICRO-CHECKER: software for identifying and correcting genotyping errors in microsatellite data. Mol. Ecol. Notes 4: 535-538. http://dx.doi.org/10.1111/j.1471$\underline{8286.2004 .00684 . x}$

Polaszek A and Walker AK (1991). The Cotesia flavipes species-complex; parasitoids of cereal stem borers in the tropics. Redia (Firenze) 74: 335-341.

Rohlf FJ (2000). NTSYS-pc: Numerical taxonomy and multivariate analysis system, version 2.1. Exeter Software Setauket, New York.

Sallam MN, Overholt WA and Kairu E (2001). Dispersal of the exotic parasitoid Cotesia flavipes in a new ecosystem. Entomol. Exp. Appl. 98: 211-217. http://dx.doi.org/10.1046/j.1570-7458.2001.00776.x

Untergasser A, Nijveen H, Rao X, Bisseling T, et al. (2007). Primer3Plus, an enhanced web interface to Primer3. Nucleic Acids Res. 35: W71-4. http://dx.doi.org/10.1093/nar/gkm306

Veiga ACP, Vacari AM, Volpe HXL, Laurentis VL, et al. (2013). Quality control of Cotesia flavipes (Cameron) (Hymenoptera: Braconidae) from different Brazilian bio-factories. Biocontrol Sci. Technol. 23: 665-673. http:// dx.doi.org/10.1080/09583157.2013.790932

Genetics and Molecular Research 15 (4): gmr.15048851 
Volpe HXL (2009). Distribuição espacial do parasitismo de Cotesia flavipes (Cameron, 1891) (Hymenoptera: Braconidae), em cana-de-açúcar. Master's thesis, UNESP, Jaboticabal. Available at [http://www.fcav.unesp.br/download/pgtrabs/ ea/m/3512.pdf] (in Portuguese).

Volpe HXL, Barbosa JC, Viel SR, Goulart RM, et al. (2014). Determination of method to evaluate parasitism and cover area for studies on Cotesia flavipes in sugarcane. Afr. J. Agric. Res. 9: 436-447. http://dx.doi.org/10.5897/AJAR2013.6991

Weising K, Nybom H, Wolff K and Meyer W (1995). DNA Fingerprinting in Plants and Fungi. CRC Press, Boca Raton.

WrightS(1951). The genetical structureofpopulations.Ann.Eugen. 15:323-354.http://dx.doi.org/10.1111/j.1469-1809.1949. tb02451.x

Genetics and Molecular Research 15 (4): gmr.15048851 